\section{RACISM AND POLITICS}

There is a definite connection between our domestic conflict over racial justice and our role in international affairs. The most inportant relation, let it be said at once, is not that which is usually proffered. It may be true that our national prestige is damaged when the plight of the American Negro is publicized abroad, that our democratic sentiments are looked at askance and that our call for freedom in other countries is turned back upon us. But to assert this fact of international political life as a reason for granting to the Negro the rights which are justly his is to lean on true but relatively. inconsequential arguments.

The Negro must have the rights of a first class citizen because they are, in justice, his. This is the first and final response to what is ultimately a moral question. All other reasons must fall into line behind this. But this fact, even when widely acknowledged, is only a prelude to the hard and urgent task of achieving racial justice in this country. The nexus between our domestic crisis over civil rights and our foreign policy becomes evident when we ask ourselves how this task is to be accomplished, when we examine the fate of major bills before Congress and the major issues which are already emerging for the next presidential campaign. Those who support a strong civil rights program must inevitably ask themselves what price they are willing to pay in terms of other legislation they would like to see enacted, what candidates they would like to see elected, what general lines of policy they would like to see developed. For there are those who are determined to see that they pay a high price.

It is easy to say, quite accurately, that the problem of making such choices is perennial with politics. And the issue of racial justice is admittedly a very special, a particularly crucial issue. But just because of that it shows more clearly than any other issue how intimately our foreign policy is related to our domestic politics.

\title{
in the magaxines
}

The Review of Politics celebrated its 25th Anniversary with the October 1963 issue. In addition to articles dealing with the evolution of the journal and of the parent institution, Notre Dame University, this issue of the quarterly contains items by Raymond J. Sontag ("The Origins of the Second World War"), Marvin Rintala ("A Generation in Politics"), Vincent De Santis ("Politics in the Gilded Age") and Stephen D. Kertesz ("The United Nations: A Hope and Its Prospects").

Dr. Kertesz has reviewed the development of the UN and its successes and timitations. He maintains that "the fundamental difficulties in international politics have persisted and have even increased since 1945 because the discrepancy between the development of physical and social sciences is greater than ever and we have not found means for clarification of fundamental issues that divide mankind."

While there has been some progress in "specific fields," Kertesz writes, it is in the area of "moral consensus on the nature of man and purposes of mankind" that progress is most imperative for the success of the world organization. "A world-wide political authority can hardly operate according to democratic principles without shared moral values.
Therefore, a reasonable way to make progress would be through enlargement of common understanding on fundamental moral issues. Neither Charter reform nor development of international law will mean genuine progress unless we succeed in basic understanding among men."

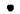

Robert F. Gray of Tulane University has contributed an "anthropological view" of political parties in new African nations below the Sahara in the quarterly Comparative Studies in Society and History (July 1963). For his study he has tempered the "morally neutral philosophy of cultural relativism" dictated by the anthropological discipline by asserting "without relativistic reservations that democracy is of great value fox any nation."

Gray has examined briefly the institutions and political methods long associated with democracy as practised in the West and then asked whether these elements are necessary for maintaining the "basic values of democracy." Following this, he has suggested the kind of democratic process for which the African nations are best equipped by reason of their own heritage. 